\title{
Tonsillar Carcinoma Spreading Metastases to Central Nervous System: Case Report and Literature Review
}

\author{
Shujhat Khan ${ }^{1}$ Giulio Anichini ${ }^{2}$ Areeb Mian ${ }^{1}$ Haider Kareem ${ }^{2}$ Nelofer Syed ${ }^{2}$ Kevin O'Neill ${ }^{2}$ \\ ${ }^{1}$ Department of Medicine, Imperial College London, London, United \\ Kingdom \\ 2 Department of neurosurgery, Charing Cross Hospital, London, \\ United Kingdom \\ Address for correspondence Shujhat Khan, MBBS, Department of \\ Medicine, Imperial College London, London SW7 2AZ, United \\ Kingdom (e-mail: sk7015@ic.ac.uk).
}

J Neurol Surg Rep 2021;82:e11-e16.

\section{Introduction}

Head and neck cancers represent a substantial burden of cancer cases worldwide with over 350,000 deaths resulting every year. ${ }^{1}$ A large proportion of head and neck cancers are oropharyngeal squamous cell carcinomas (OPSCC) with studies suggesting a rising trend among populations. Tonsillar cancers represent $44 \%$ of all human papillomovairus (HPV)-related oropharyngeal cancers and can be identified as SCC (90\%) arising primarily from the mucosal lining of the oral cavity, while a small number are classified as lymphomas. ${ }^{2,3}$

The etiology is complex and is often associated with several risk factors including smoking and alcohol abuse. ${ }^{4}$ HPV infection (specifically type 16) is the most dominant risk factor in patients who do not consume alcohol or tobacco, functioning through mutation of p53 and retinoblastoma tumor suppressor pathways. ${ }^{5,6}$ It appears to be largely responsible for the rising incidence of OPSCC. ${ }^{7}$ The increasing prevalence of HPV-related oropharyngeal carcinoma has a received

June 10,2020

accepted after revision

November 17, 2020
DOI https://doi.org/

10.1055/s-0041-1726305.

ISSN 2193-6358.

\footnotetext{
(C) 2021. The Author(s).

This is an open access article published by Thieme under the terms of the Creative Commons Attribution-NonDerivative-NonCommercial-License, permitting copying and reproduction so long as the original work is given appropriate credit. Contents may not be used for commercial purposes, or adapted, remixed, transformed or built upon. (https://creativecommons.org/ licenses/by-nc-nd/4.0/) Georg Thieme Verlag KG, Rüdigerstraße 14, 70469 Stuttgart, Germany
} 
more favorable prognosis than non-HPV associated oropharyngeal carcinoma, while smoking, specifically, accounts for a significantly worsened prognosis. ${ }^{8-10}$ The increasing prevalence of oropharyngeal carcinomas may be linked to the increase of HPV cases among younger individuals. ${ }^{2,7}$

Tonsils have a rich supply of lymphatic tissue, which provides an easy path for metastases to reach regional lymph nodes. Cancerous cells may spread locally to the surrounding tissue of the oropharynx including the base of the tongue, the soft palate, and the posterior wall of the throat. Alternatively, they can access the lymphatic system, which usually involves the cervical nodes. From here, they can access more distant regions. ${ }^{11}$ However, distal metastases are rare.

The incidence of distal metastases varies extensively in literature ranging from 3 to $31 \%{ }^{12,13}$ This is influenced by various factors such as primary tumor location, histological differentiation, staging, and degree of loco regional control. The most common sites include the liver, lungs, bones, and mediastinal sites. ${ }^{14,15}$ Literature suggesting tonsillar metastases to the central nervous system (CNS) is scarce, indicative of the unusual incidence of this clinical presentation. It typically only occurs in 1 to $2 \%$ of cases and generally tends to appear in the later stages of the disease. ${ }^{16}$

We present a case showing multiple intracranial secondary lesions from tonsillar carcinoma alongside the relevant literature.

\section{Case Description}

A 51-year-old left-handed man with a background of HPV-16 positive tonsil squamous cell carcinoma was referred to our service after a tonic-clonic seizure and a radiological diagnosis of secondary brain deposits. His original disease presented in October 2013 and was treated in Singapore with a short course of Cisplatin and radiotherapy, completed by the end of the same year. From then, follow-up has been arranged locally until 2015 . The patient subsequently relocated to the United Kingdom, and his care was taken over by a dedicated head and neck center.

In summer 2017, the patient presented radiological signs of recurring disease with diffuse metastases on lungs, liver, and pancreas. The liver and pancreatic deposits were biopsied and treated with a chemotherapeutic regimen of Cisplatin, 5-Fluorouracil, and Cetuximab in October 2017.

In November 2017, a computed tomography scan of the head was performed in the accident and emergency department following a tonic and clonic, and the patient was found to have three intra-axial secondary deposits on the right hemisphere-located in the temporal pole, temporo-parietal, and trigonal region, respectively. At this point, the patient was treated with three sessions of stereotactic radiotherapy (Cyberknife). In June 2018, the patient was started on a course of Capecitabine. This was paused in September 2018 during the few weeks surrounding his surgery, with irreversible electroporation (NanoKnife) for his pancreatic and liver deposits. He was subsequently also started on Nivolumab.

At the time of our assessment, the patient was found to be alert and orientated with a GCS of 15 . The patient denied any

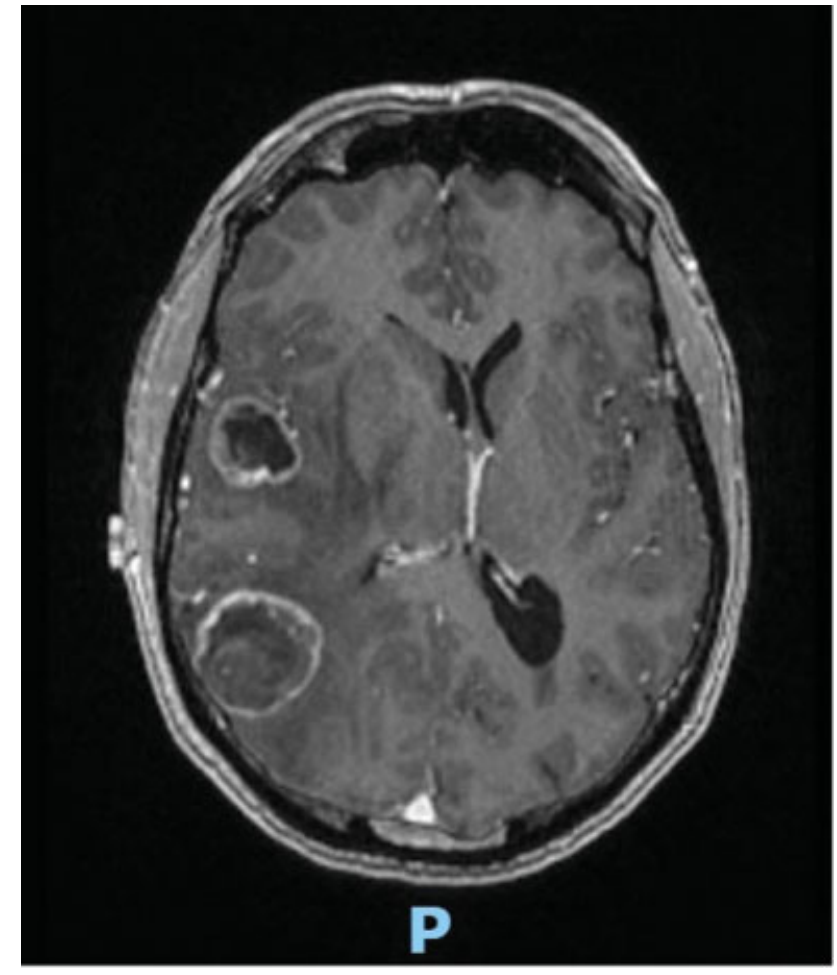

Fig. 1 Magnetic resonance imaging demonstrating multifocal supratentorial intracranial deposits exclusively present in the right hemisphere in the supratentorial compartment.

pain or nausea, pupils were equal and reacting to light, and sensation and motor function was intact. There were no other significant medical problems except asymptomatic sinus bradycardia. Family history illustrated paternal celiac disease and late onset diabetes. Personal history was negative for smoking or alcohol intake.

An updated magnetic resonance imaging (MRI) scan of the head with gadolinium injection revealed multifocal supratentorial intracranial deposits in the brain (-Fig. 1). While almost exclusively present in the right parieto-temporal region in the supratentorial compartment, there were also deposits of metastatic tissue present in the peripheral right cerebellum, as well as in the inferior cerebellum adjacent to the tonsils. The largest metastatic deposit measured $3.3 \mathrm{~cm}$ in the right parieto-temporal region with surrounding edema and distortion of the midline structures to the left. A second large metastatic deposit was seen in the temporo-polar area. A third relatively voluminous deposit was located at the level of the right lateral ventricle's atrium. The patient was initially treated with linear accelerator (LINAC) stereotactic radiation and adjuvant chemotherapy in the form of Nivolumab.

A few weeks after stereotatic radiosurgery (SRS), the patient started to experience increasing unsteadiness and left sided mild hemiparesis. A repeat MRI of the head showed increased mass effect at the level of the right hemisphere, in the form of both peri-lesional edema and increased size of the three main metastatic deposits. The patient was then started on a course of steroids, and his case was rediscussed in our neuro-oncology multidisciplinary team (MDT). 
Palliative surgery was considered to be a viable option at this point to relieve the symptoms and avoid imminent deterioration considering the patient's young age and good performance status. Conservative treatment and a new course of SRS were also discussed. After having considered all treatment options, the patient and his family expressed their will to proceed with surgery, which was performed in May 2018.

The surgical plan was to remove both the parietal and temporal deposits, with attempt to remove the intraventricular one in the same session. The operation was performed under general anesthesia with right-sided temporal and parietal approaches. After Mayfield clamp fixation, a single trauma flap was performed under neuronavigation guidance, and then two mini-craniotomies centered on the lesions were obtained. Resection of both superficial deposits was performed under microscope magnification. The resection was complicated by prolonged hemostasis and bleeding tendency, despite the patient being in good clinical conditions, without known bleeding disorder and no anticoagulant or antiplatelets therapy.

However, removal of the intraventricular lesion was deemed too risky due to the proximity of the optic radiation physically surrounding the ventricular atrium and the lateral surface of the tumor, as well as the increased tendency to hemorrhage and technical difficulty associated with removal from this location. After hemostasis, the dura layer was stitched back, the bone flap was screwed back in place, and a subgaleal drain inserted before stitching the skin.

The patient awoke with no obvious neurological deficits and was transferred to the high dependency unit as a precaution postsurgery. Early ( $<24$ hours) postoperative MRI scans showed complete resection of the parietal and temporal lesions with no obvious postoperative hematoma. Interestingly, the patient started to deteriorate neurologically during the afternoon of the first postoperative day. Gradual onset of severe headache was reported by the caring team. The headache was followed by rapidly progressive left side hemiparesis (grade 2.5) and a left facial droop.

A head CT (-Fig. 2) was therefore repeated and demonstrated an anterior tumor cavity hematoma, with increased perilesional edema and mass effect. The hematoma was evacuated in emergency. The surgery was uneventful, and the patient subsequently regained strength in his limbs with resolution of the left-sided hemiparesis. No significant neurological symptoms were noted at discharge, and the patient was therefore retreated with gamma knife radiotherapy on both the surgical cavities and the remaining metastatic deposits.

Precisely 4 months after the SRS treatment, the patient experienced a new clinical decline, with worsening headache, intermittent unexplained cough, left-sided homonymous hemianopia, and hyperacusis. Mild hemiparesis was also noted. An MRI of the head was requested, which showed a large tumor recurrence at the level of the previous parietal location. Extensive edema and midline shift were also present, with an overall worse mass effect and distortion of the midbrain. An interval increase in the size of the metastatic lesion within the right lateral ventricle trigone was also

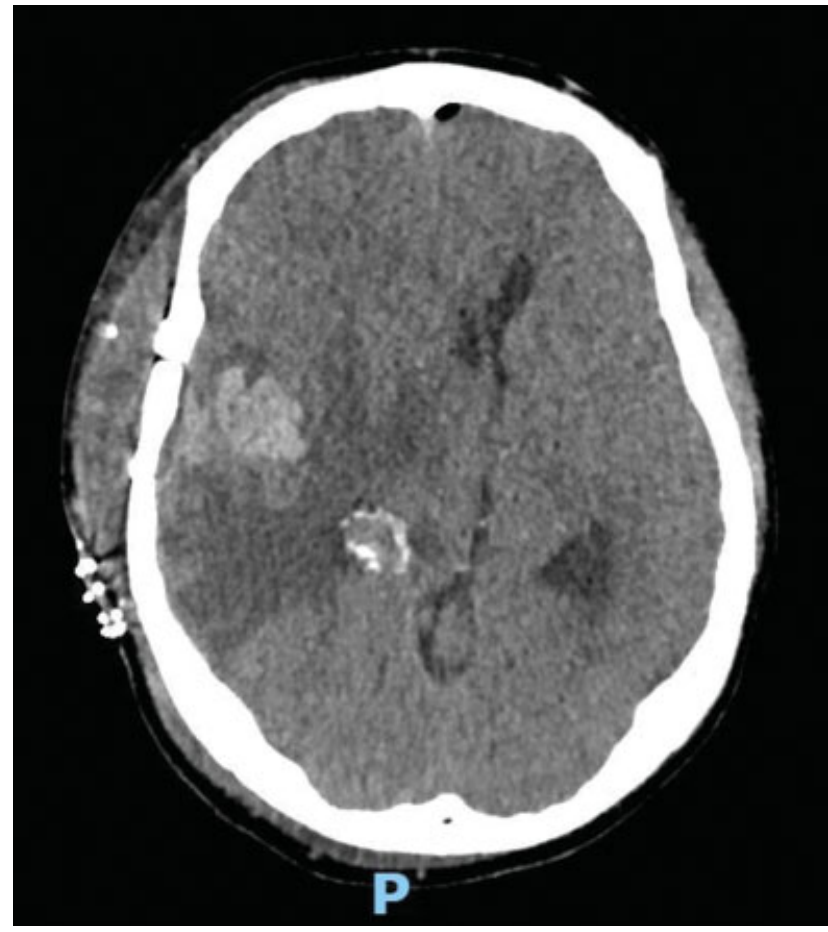

Fig. 2 Computed tomography demonstrating intraparenchymal hematoma within the resection cavity in the right temporal lobe.

noted, as well as two new metastatic deposits that were present in the left frontal lobe. The left cerebellar metastasis had also increased in size. Life-saving surgery was performed the day, following the hospital admission in September 2018. Reopening of the previously performed parietal approach was performed, and the resection was performed as previously described.

The patient's postoperative course was uneventful and he reported marked improvement of his visual preoperative symptoms. Together with his usual medications, the patient was started on Capecitabine $1,500 \mathrm{mg}$ oral twice daily 2 weeks after surgery. The case was rediscussed at the neuro-oncology MDT, and, considering the disease progression, palliative whole brain radiotherapy was considered and started after 1 month from the surgery. Unfortunately, due to intervening pneumonia, the patient passed away in November 2018, 1 year after the diagnosis of brain metastatic deposits and 5 years after the primary diagnosis.

\section{Discussion}

Tonsillar carcinomas are rare, only representing a small portion of all cancers. ${ }^{17,18}$ However, the incidence and consequently the prevalence is increasing worldwide. This seems to be due recent molecular and epidemiological evidence suggesting that the HPV plays a critical role in the pathogenesis of tonsillar SCC.,16,19-21 The rate of incidence of incidence increases after the 4 th decade of life with men affected three to four times more often than women. ${ }^{17,18}$

Tonsillar carcinoma distant metastasis (DM) is extremely uncommon (3-30\% of cases). ${ }^{12,13}$ The incidence of DMs is 
influenced by the location of the primary tumor, size of the tumor, and the presence or absence of regional control above the clavicle. ${ }^{14}$ Patients with advanced nodal disease and $\mathrm{T}$ staging are at a much higher risk of DM. Metastases to the cervical lymph nodes is an important prognostic factor in these patients as it has been linked to a decreased survival rate. ${ }^{22}$ Metastasis to the lung is most common with SCC $66 \%$ of all DMs. Other sites include bone (22\%), liver (10\%), skin, mediastinum, and rarely the bone marrow. ${ }^{14}$

Distant metastasis of tonsillar carcinoma and other oropharyngeal cancers can occur either by perineural spread or by a hematogenous route. ${ }^{23}$ Neumann in 1862 were the first to report neural metastasis of head and neck SCC, ${ }^{24}$ Shattock in 1921 raised the possibility spread along cranial nerves. ${ }^{25}$ However, it was not until 1927 two cases of SCC were reported that showed spread intracranially along the maxillary division of the cranial nerve $\mathrm{V} .^{23}$ Prostate, breast, pancreas, and oesophageal carcinoma metastasis to the brain is known to occur via perineural spaces. ${ }^{26}$ Spread of SCC along branches of the trigeminal nerve into the cranium has been reported by several previous investigators. ${ }^{27-30}$ Thus, tonsillar carcinoma metastasis to the brain may occur either by hematogenous spread or spread to other sites followed by perineural metastasis.

The CNS is a very rare site for DM of tonsillar carcinoma, with only a few cases reported in literature. A literature review summary is reported in - Table $\mathbf{1}$. To the best of our knowledge, these are the cases reported so far. Given a history of head and neck SCC, the question of how intensely pre/postoperative screening should be performed remains. Ferlito et $\mathrm{al}^{14}$ recommend preoperative chest X-ray in all cases, and if the primary tumor and nodal status indicated a high risk of pulmonary metastasis, then preoperative CT of the chest should be done.

Postoperatively, annual X-rays of the chest are usually sufficient but in higher risk patients a chest X-ray should be

Table 1 Literature review of reported cases of tonsillar squamous cell carcinomas metastasis to the brain

\begin{tabular}{|c|c|c|c|c|c|c|}
\hline Study (Year) & Sex & $\begin{array}{l}\text { Age at } \\
\text { diagnosis } \\
\text { (y) }\end{array}$ & $\begin{array}{l}\text { Symptoms and } \\
\text { signs }\end{array}$ & Radiological findings & Treatment & $\begin{array}{l}\text { Prognosis from } \\
\text { detection of in- } \\
\text { tracranial dis- } \\
\text { ease }\end{array}$ \\
\hline $\begin{array}{l}\text { Dobelbower et al } \\
(2009)^{16}\end{array}$ & $\mathrm{~F}$ & 63 & $\begin{array}{l}\text { Vertigo and gait } \\
\text { impairment }\end{array}$ & $\begin{array}{l}\text { Met lesions in left frontal lobe } \\
+ \text { right parieto-occipital region } \\
\text { on MRI }\end{array}$ & $\begin{array}{l}\text { Surgery + radio- } \\
\text { therapy }\end{array}$ & 10 months \\
\hline $\begin{array}{l}\text { Ballantyne et al } \\
(1963)^{23}\end{array}$ & $\mathrm{M}$ & 51 & $\begin{array}{l}\text { VI cranial nerve } \\
\text { palsy }\end{array}$ & $\begin{array}{l}\text { Clival deposit with left cavern- } \\
\text { ous sinus involvement on MRI }\end{array}$ & Systemic therapy & 4 months \\
\hline Oh et al $(2013)^{5}$ & $\mathrm{M}$ & 53 & $\begin{array}{l}\text { Headache, deaf- } \\
\text { ness, diplopia, } \\
\text { nasal regurgita- } \\
\text { tion, and hoarse- } \\
\text { ness } \\
\text { Bilateral VIlth, } \\
\text { Vlllth, and Xllth } \\
\text { cranial nerve } \\
\text { palsies }\end{array}$ & $\begin{array}{l}\text { Foci in prepontine cistern sug- } \\
\text { gestive of subarachnoid } \\
\text { metasteses }\end{array}$ & Radiotherapy & $<4$ months \\
\hline $\begin{array}{l}\text { Goodwin et al } \\
(2001)^{15}\end{array}$ & $\mathrm{M}$ & 42 & $\begin{array}{l}\text { Sudden hearing } \\
\text { loss on left side }\end{array}$ & $\begin{array}{l}\text { Lesion at left base of skull in- } \\
\text { vading through the jugular fo- } \\
\text { ramen toward the } \\
\text { cerebellopontine angle } \\
\text { Invasion of the lateral medulla } \\
\text { and cerebellum }\end{array}$ & Radiotherapy & 3 months \\
\hline $\begin{array}{l}\text { Shiboski et al } \\
(2005)^{2}\end{array}$ & M & 61 & $\begin{array}{l}\text { Left sided weak- } \\
\text { ness, headache } \\
\text { and blurry vision }\end{array}$ & $\begin{array}{l}\text { Calvarial and frontoparietal } \\
\text { homogenous, cystic, contrast- } \\
\text { enhancing mass with edema } \\
\text { extending across the sagittal } \\
\text { sinus }\end{array}$ & $\begin{array}{l}\text { Stereotactic } \\
\text { bifrontal craniot- } \\
\text { omy with intra- } \\
\text { dural tumor } \\
\text { resection + ra- } \\
\text { diotherapy + } \\
\text { chemotherapy }\end{array}$ & $>7$ months \\
\hline Blot et al $(1988)^{4}$ & $\mathrm{M}$ & 34 & $\begin{array}{l}\text { Backache, severe } \\
\text { tenderness over } \\
\text { lumbar region, } \\
\text { and loss of ability } \\
\text { to walk/stand }\end{array}$ & $\begin{array}{l}\text { Wedge compression fracture } \\
\text { of L4 vertebral body and al- } \\
\text { tered marrow signal intensity } \\
\text { with associated periosseous } \\
\text { component at L3 and L4 level } \\
\text { + multiple altered signal in- } \\
\text { tensity in both cerebellar } \\
\text { hemispheres and also similar } \\
\text { deposits at right parietal, left } \\
\text { temporal, parietal and occipital } \\
\text { bony calvarium, and adjacent } \\
\text { scalp resulting in bony } \\
\text { destruction }\end{array}$ & $\begin{array}{l}\text { Radiotherapy } \\
\text { (whole brain and } \\
\text { lumbar spine) }\end{array}$ & $\begin{array}{l}\text { 3-month survival } \\
\text { following com- } \\
\text { pletion of } \\
\text { treatment }\end{array}$ \\
\hline
\end{tabular}


performed every 3 to 6 months. As seen in both the cases included above and our patient, presenting neurological symptoms are diverse. Due to the rapid progression and poor outcomes associated with intracranial spread, an argument can be made to screen patients for intracranial disease given a previous history of head and neck SCC.

The management of patients with primary oropharyngeal SCC remains controversial. Early stage oropharyngeal carcinomas treated with surgery or radiation alone are equally successful. In more late stage disease, a combination of surgery and postoperative radiotherapy provides a superior outcome compared with chemoradiation therapy. ${ }^{31} \mathrm{Al}-\mathrm{Khu}-$ dari et $\mathrm{al}^{32}$ described the case of an HPV-associated oligometastatic oropharyngeal SCC and concluded that these patients may be appropriate for definitive treatment approaches, given the excellent treatment response and prognosis of HPV-positive disease in general. The case presented by Banerjee et $\mathrm{al}^{33}$ demonstrates the ability of rapid spread of tonsillar carcinoma.

Aggressive follow-up evaluation must be performed after completing treatment courses for such cases. Our case history stresses the difficulty in managing SCC with brain metastatic deposits. Current guidelines recommend using surgical excision along with chemotherapy such as fluorouracil with or without cetuximab for metastatic oropharyngeal carcinoma. ${ }^{34}$ However, with limited data and treatment outcomes, there is no treatment guideline for patients with this rare presentation. In our case, the latter was chosen both by clinicians and the patient. With one exception, ${ }^{33}$ the survival of our case was higher than the average reported in literature (-Table 1). However, despite maintaining a good performance status, the prognosis was ultimately poor. More data are thus desirable to better define treatment guidelines and protocols when SCC brain metastases are present.

\section{Funding \\ None.}

\section{Conflict of Interest}

None declared.

\section{References}

1 Vigneswaran N, Williams MD. Epidemiologic trends in head and neck cancer and aids in diagnosis. Oral Maxillofac Surg Clin North Am 2014;26(02):123-141

2 Shiboski CH, Schmidt BL, Jordan RC. Tongue and tonsil carcinoma: increasing trends in the U.S. population ages 20-44 years. Cancer 2005;103(09):1843-1849

3 Hocking JS, Stein A, Conway EL, et al. Head and neck cancer in Australia between 1982 and 2005 show increasing incidence of potentially HPV-associated oropharyngeal cancers. Br J Cancer 2011;104(05):886-891

4 Blot WJ, McLaughlin JK, Winn DM, et al. Smoking and drinking in relation to oral and pharyngeal cancer. Cancer Res 1988;48(11): 3282-3287

5 Oh JE, Kim JO, Shin JY, et al. Molecular genetic characterization of p53 mutated oropharyngeal squamous cell carcinoma cells transformed with human papillomavirus E6 and E7 oncogenes. Int J Oncol 2013;43(02):383-393
6 Rampias T, Sasaki C, Weinberger P, Psyrri A. E6 and e7 gene silencing and transformed phenotype of human papillomavirus 16-positive oropharyngeal cancer cells. J Natl Cancer Inst 2009; 101(06):412-423

7 Näsman A, Attner P, Hammarstedt L, et al. Incidence of human papillomavirus (HPV) positive tonsillar carcinoma in Stockholm, Sweden: an epidemic of viral-induced carcinoma? Int J Cancer 2009;125(02):362-366

8 Worden FP, Kumar B, Lee JS, et al. Chemoselection as a strategy for organ preservation in advanced oropharynx cancer: response and survival positively associated with HPV16 copy number. J Clin Oncol 2008;26(19):3138-3146

9 Fakhry C, Westra WH, Li S, et al. Improved survival of patients with human papillomavirus-positive head and neck squamous cell carcinoma in a prospective clinical trial. J Natl Cancer Inst 2008;100(04):261-269

10 Maxwell JH, Kumar B, Feng FY, et al. Tobacco use in HPV-positive advanced oropharynx cancer patients related to increased risk of distant metastases and tumor recurrence. Clin Cancer Res 2010; 16(04):1226

11 L DP Shruti D. Diseases of Ear, Nose and Throat. 7th ed. Elsevier India; 2017:554

12 Brugère JM, Mosseri VF, Mamelle G, et al. Nodal failures in patients with $\mathrm{NO} \mathrm{N}+$ oral squamous cell carcinoma without capsular rupture. Head Neck 1996;18(02):133-137

13 Okamoto M, Nishimine M, Kishi M, et al. Prediction of delayed neck metastasis in patients with stage I/II squamous cell carcinoma of the tongue. J Oral Pathol Med 2002;31(04): 227-233

14 Ferlito A, Shaha AR, Silver CE, Rinaldo A, Mondin V. Incidence and sites of distant metastases from head and neck cancer. ORL J Otorhinolaryngol Relat Spec 2001;63(04):202-207

15 Goodwin WJ. Distant metastases from oropharyngeal cancer. ORL J Otorhinolaryngol Relat Spec 2001;63(04):222-223

16 Dobelbower MC, Nabell L, Markert J, Carroll W, Said-Al-Naief N, Meredith R. Cancer of the tonsil presenting as central nervous system metastasis: a case report. Head Neck 2009;31(01): $127-130$

17 Cook MB, Dawsey SM, Freedman ND, et al. Sex disparities in cancer incidence by period and age. Cancer Epidemiol Biomarkers Prev 2009;18(04):1174-1182

18 Golas SM. Trends in palatine tonsillar cancer incidence and mortality rates in the United States. Community Dent Oral Epidemiol 2007;35(02):98-108

19 Charfi L, Jouffroy T, de Cremoux P, et al. Two types of squamous cell carcinoma of the palatine tonsil characterized by distinct etiology, molecular features and outcome. Cancer Lett 2008;260 (1-2):72-78

20 D'Souza G, Kreimer AR, Viscidi R, et al. Case-control study of human papillomavirus and oropharyngeal cancer. N Engl J Med 2007;356(19):1944-1956

21 Näsman A, Nordfors C, Holzhauser S, et al. Incidence of human papillomavirus positive tonsillar and base of tongue carcinoma: a stabilisation of an epidemic of viral induced carcinoma? Eur J Cancer 2015;51(01):55-61

22 Shimizu K, Inoue H, Saitoh M, et al. Distribution and impact of lymph node metastases in oropharyngeal cancer. Acta Otolaryngol 2006;126(08):872-877

23 Ballantyne AJ, McCarten AB, Ibanez ML. The extension of cancer of the head and neck through peripheral nerves. Am J Surg 1963; 106:651-667

24 Neumann E. Secundäre Cancroidinfiltration des Nervus mentalis bei einem Fall von Lippencancroid. BriefCommunication. Arch Pathol Anat Physiol Klin Med 1862;24(01):201-202

25 Shattock SG. Invasion of the nerves in carcinoma of the sublingual salivary gland, associated with carcinoma of the tongue. Proc $\mathrm{R}$ Soc Med 1922;15(Pathol Sect):13-16 
26 Ackerman LVDR, Juan A, Spjut JH, Ackerman LV. Ackerman and Del Regato's Cancer: Diagnosis, Treatment and Prognosis. 5th ed. 1977. Doi: 10.1002/hed.2890050619

27 Bitoh S, Hasegawa H, Ohtsuki H, Obashi J, Kobayashi Y. Parasellar metastases: four autopsied cases. Surg Neurol 1985;23(01):41-48

28 Dodd GD, Dolan PA, Ballantyne AJ, Ibanez ML, Chau P. The dissemination of tumors of the head and neck via the cranial nerves. Radiol Clin North Am 1970;8(03):445-461

29 Cuneo HM, Rand CW. Tumors of the gasserian ganglion; tumor of the left gasserian ganglion associated with enlargement of the mandibular nerve; a review of the literature and case report. J Neurosurg 1952;9(05):423-431

30 Trobe JD, Hood CI, Parsons JT, Quisling RG. Intracranial spread of squamous carcinoma along the trigeminal nerve. Arch Ophthalmol 1982;100(04):608-611
31 Da Mosto MC, Zanetti F, Boscolo-Rizzo P. Pattern of lymph node metastases in squamous cell carcinoma of the tonsil: implication for selective neck dissection. Oral Oncol 2009;45(03):212-217

32 Al-Khudari S, Guo S, Chen Y, et al. Solitary dural metastasis at presentation in a patient with untreated human papillomavirusassociated squamous cell carcinoma of the oropharynx. Head Neck 2014;36(10):E103-E105

33 Banerjee S, Kundu D, Mukherjee M, Maiti PK. Early stage squamous cell carcinoma of the tonsil presenting with multiple organ metastases including skin and brain after successful local treatment. J Cancer Metastasis Treat 2015. Doi: 10.4103/23944722.152761

34 practice $\mathrm{Bb}$. Oropharyngeal cancer: treatment algorithm. BMJ Best Practice BMJ. Accessed March 3, 2019 at: https://bestpractice.bmj.com/topics/en-gb/1114/treatmentalgorithm 